\title{
FORMY POZYSKIWANIA MATERIAŁÓW DYDAKTYCZNYCH PRZEZ STUDENTÓW KIERUNKU FINANSE I RACHUNKOWOŚĆ
}

\section{THE FORMS OF ACQUIREMENT OF DIDACTIC MATERIALS BY STUDENTS OF THE FINANCE AND ACCOUNTING SPECIALITY}

Instytut Rachunkowości, Uniwersytet Szczeciński

ul. Adama Mickiewicza 64, 71-101 Szczecin, e-mail: tkiziukiewicz@wp.pl, kr234@wneiz.pl

\begin{abstract}
Summary. The use of didactic materials is one of the fundamental factors determining independent work of students to acquire and extend their knowledge. The methods of acquirement of these materials may vary, and the choice of each method affects quality and efficiency of the learning process. The purpose of the paper was to examine and indicate the most popular forms of acquirement of didactic materials by students. In order to achieve this aim, a survey was conducted, in which 101 full-time and part-time students of Bachelor and Master levels of the Finance and Banking speciality in the Faculty of Economics and Management at the University of Szczecin took part. The results of the survey indicate that students of the Bachelor level make photocopies or take photographs of materials provided by the lecturers or their classmates, which means that they limit their sources to the knowledge shared in class. On the other hand, the full-time and part-time students of the Master level strive to extend their knowledge, which is denoted by the domination of borrowing books from libraries, using reading rooms and buying books.
\end{abstract}

Słowa kluczowe: uczenie się, materiały dydaktyczne, formy pozyskiwania.

Key words: learning, didactic material, forms of acquirement.

\section{WSTĘP}

Proces uczenia się, związany z nabywaniem wiedzy przez studiujących, wymaga przede wszystkim ich samodzielnej pracy, polegającej na zdobywaniu nowych i poszerzaniu już posiadanych informacji (Michalski 1993, cyt. za: Janowicz 2016). Jednym z podstawowych czynników, przesądzających o powodzeniu, jest - oprócz nauczania - korzystanie przez uczących się ze źródeł stanowiących materiał dydaktyczny. Materiał ten, w zależności od dziedziny nauki i konkretnego przedmiotu, może występować w różnej formie, na przykład w postaci nauczania (wykłady, ćwiczenia, konwersatoria, laboratoria), literatury fachowej, podręczników, skryptów, konspektów, zbiorów zadań (w postaci tradycyjnej i elektronicznej). Skłonność do korzystania z określonych źródeł zależy nie tylko od przedmiotu, ale też od formy uczenia się, na przykład pamięciowej, przez rozwiązywanie problemów, case study, działanie, dyskusję (por. Jankowska i Leśnikowska-Matusiak 2011). Różne też mogą być sposoby pozyskiwania materiału dydaktycznego, co ma związek z preferowaną przez studiujących formą uczenia się, a także z innymi czynnikami, takimi jak łatwość dostępu do materiału dydaktycznego czy związane z tym koszty. 
Celem artykułu jest wskazanie najpopularniejszych sposobów pozyskiwania materiałów dydaktycznych przez studentów kierunku finanse i rachunkowość, a ponadto ocena wyników badań przez pryzmat stopnia efektywności uczenia się w sensie zdobywania nowej wiedzy i pogłębiania posiadanej.

\section{MATERIAK, METODY I GRUPA BADAWCZA}

$\mathrm{Na}$ potrzeby artykułu zastosowano metodę badań ankietowych. W tym celu została opracowana ankieta badawcza, w której zamieszczono 10 możliwych form pozyskiwania materiałów dydaktycznych. Zadaniem ankietowanych było uszeregowanie w oddzielnej kolumnie źródeł pozyskiwania materiałów dydaktycznych według częstotliwości korzystania z nich, a więc najczęściej wykorzystywane źródło powinno otrzymać nr 1, kolejne nr 2 itd. aż do najmniej wykorzystywanego źródła z nr 10. Jeżeli ankietowani nigdy nie korzystali z danego źródła, wpisywali 0.

Ankietę przeprowadzono wśród studentów studiów stacjonarnych i niestacjonarnych I i II stopnia z kierunku finanse i rachunkowość na Wydziale Nauk Ekonomicznych i Zarządzania Uniwersytetu Szczecińskiego (US). Łącznie ankietowano 101 osób, w tym: 77 studentów ze studiów stacjonarnych i 24 ze studiów niestacjonarnych. Wśród ankietowanych było 70 studentów studiów I stopnia (56 ze studiów stacjonarnych i 14 ze studiów niestacjonarnych) i 31 studentów studiów II stopnia (21 ze studiów stacjonarnych i 10 ze studiów niestacjonarnych).

Mając na uwadze strukturę badanej populacji, dokonano podziału zgromadzonego materiału na następujące grupy:

a) studenci ze studiów I stopnia

- stacjonarnych, z podziałem na studiujących na 1. i 3. roku;

- niestacjonarnych z 3. roku;

b) studenci ze studiów II stopnia

- stacjonarnych z 2. roku;

- niestacjonarnych z 2. roku.

Wyodrębnienie wymienionych grup miało na celu ustalenie, czy preferencje studentów dotyczące form pozyskiwania materiałów dydaktycznych w poszczególnych grupach respondentów są podobne czy zróżnicowane.

\section{ANALIZA FORM POZYSKIWANIA ŹRÓDEŁ DYDAKTYCZNYCH PRZEZ STUDENTÓW STUDIÓW LICENCJACKICH}

W pierwszej kolejności badaniem zostały objęte ankiety wypełnione przez studentów pierwszego roku stacjonarnych studiów licencjackich w myśl założenia, że ich preferencje co do form pozyskiwania materiałów dydaktycznych są inne niż studentów trzeciego roku studiów licencjackich. Ponadto była to najliczniejsza grupa ankietowanych. Wyniki badań są zamieszczone w tab. 1. 
Tabela 1. Formy pozyskiwania źródeł przez studentów pierwszego roku stacjonarnych studiów licencjackich (46 ankiet)

\begin{tabular}{|c|c|c|c|c|c|c|c|c|c|c|c|}
\hline $\begin{array}{c}\text { Miejsce } \\
\text { Pytanie }\end{array}$ & I & II & III & IV & V & VI & VII & VIII & IX & X & 0 \\
\hline 1 & 3 & 4 & $\mathbf{7}$ & 4 & 3 & 3 & 6 & 6 & 5 & - & 5 \\
\hline 2 & 2 & 1 & 8 & 4 & $\mathbf{9}$ & 4 & 5 & 4 & 1 & 2 & 6 \\
\hline 3 & 1 & 1 & 2 & 3 & 4 & $\mathbf{1 0}$ & 7 & 3 & 7 & 2 & 6 \\
\hline 4 & 3 & $\mathbf{1 2}$ & 6 & 10 & 3 & 2 & 2 & 4 & 2 & - & 2 \\
\hline 5 & $\mathbf{1 7}$ & 3 & 4 & 7 & 3 & 1 & 3 & 3 & 2 & 1 & 2 \\
\hline 6 & 2 & $\mathbf{7}$ & 2 & 2 & $\mathbf{7}$ & 5 & 4 & 5 & 4 & 2 & 6 \\
\hline 7 & - & 2 & 3 & 3 & 1 & 2 & 3 & 4 & 8 & 8 & $\mathbf{1 2}$ \\
\hline 8 & 5 & 3 & 7 & 1 & 5 & 8 & 2 & 1 & 1 & $\mathbf{9}$ & 4 \\
\hline 9 & 2 & $\mathbf{8}$ & 2 & 4 & 4 & 5 & 3 & 3 & 3 & 4 & 6 \\
\hline 10 & $\mathbf{1 4}$ & 6 & 7 & 6 & 3 & 2 & 2 & 3 & 2 & - & 1 \\
\hline
\end{tabular}

Pogrubioną czcionką wyróżniono pozycje dominujące.

Jak wynika z tab. 1, na pierwszym miejscu jako źródło pozyskiwania materiałów do uczenia się 17 osób wskazało kserowanie tekstów przekazywanych przez wykładowców. Studenci z drugiej pod względem liczebności grupy (14 osób) na pierwszym miejscu umieścili wykonywanie zdjęć materiałów dydaktycznych. Studenci z kolejnej co do wielkości grupy (12 osób) pozyskują materiał, kserując teksty od kolegów. Świadczy to o tym, że 93\% ankietowanych, korzystając z ksero i zdjęć, nie angażuje się w poszukiwanie materiałów umożliwiających poszerzenie wiedzy zdobytej na zajęciach. Niepokojący w wypadku tej grupy jest fakt, że korzystanie ze zbiorów bibliotecznych (wypożyczenia, czytelnia) zostało wymienione przez badanych dopiero na piątej pozycji (9 osób), a korzystanie z czytelni na szóstym miejscu (10 osób).

$\mathrm{Na}$ końcowych miejscach znajdują się różne formy zakupu książek, przy czym 59\% ankietowanych nigdy (oznaczenie 0) nie kupuje książek bezpośrednio od wydawców, poprzez księgarnie internetowe lub $w$ inny sposób. Jeżeli takie zakupy są dokonywane, to sporadycznie, o czym świadczy fakt, że w ankiecie znajdowały się one na końcowych miejscach.

Druga grupa respondentów ze stacjonarnych studiów licencjackich studiuje, jak wspomniano wyżej, na trzecim roku. Ankiety wypełniło 10 osób. Uzyskane wyniki są zestawione w tab. 2.

Tabela 2. Formy pozyskiwania źródeł przez studentów trzeciego roku stacjonarnych studiów licencjackich (10 ankiet)

\begin{tabular}{|c|c|c|c|c|c|c|c|c|c|c|c|}
\hline Miejsce & I & II & III & IV & V & VI & VII & VIII & IX & X & 0 \\
\hline 1 & - & - & - & 1 & - & 2 & - & 1 & 3 & 3 & - \\
\hline 2 & 1 & - & 1 & - & 1 & 3 & $\mathbf{3}$ & - & 1 & - & - \\
\hline 3 & - & - & - & 1 & 1 & 3 & 3 & 2 & - & - & - \\
\hline 4 & 3 & 4 & - & 2 & - & - & 1 & - & - & - & - \\
\hline 5 & 2 & 3 & $\mathbf{3}$ & 1 & 1 & - & - & - & - & - & - \\
\hline 6 & - & - & - & - & 1 & - & 1 & 2 & $\mathbf{4}$ & 1 & 1 \\
\hline 7 & - & - & - & - & 1 & 1 & - & $\mathbf{4}$ & 2 & 2 & - \\
\hline 8 & - & - & 2 & 1 & $\mathbf{2}$ & - & 2 & - & 1 & 1 & 1 \\
\hline 9 & 1 & 1 & 1 & $\mathbf{3}$ & 1 & - & - & 1 & 1 & 1 & - \\
\hline 10 & 3 & 3 & $\mathbf{3}$ & - & 1 & - & - & - & - & - & - \\
\hline
\end{tabular}

Pogrubioną czcionką wyróżniono pozycje dominujące. 
Studenci z tej grupy na pierwszym i drugim miejscu zamieścili kserowanie tekstów od kolegów i wykonywanie zdjęć materiałów dydaktycznych. Jak w wypadku pierwszej omówionej grupy, na dalszych miejscach znalazły się zakupy książek z różnych źródeł, a także korzystanie z biblioteki i czytelni.

Trzecią grupą badawczą były osoby studiujące na drugim roku niestacjonarnych studiów I stopnia (14 osób). Uzyskane wyniki są przedstawione w tab. 3.

Tabela 3. Formy pozyskiwania źródeł przez studentów drugiego roku niestacjonarnych studiów licencjackich (14 ankiet)

\begin{tabular}{|c|c|c|c|c|c|c|c|c|c|c|c|}
\hline Miejsce & I & II & III & IV & V & VI & VII & VIII & IX & X & 0 \\
\hline 1 & 2 & 2 & 1 & - & 1 & 2 & 2 & $\mathbf{4}$ & - & - & - \\
\hline 2 & 1 & 1 & - & - & 1 & 2 & 2 & 1 & $\mathbf{3}$ & $\mathbf{3}$ & - \\
\hline 3 & 1 & - & 1 & 1 & - & 2 & 1 & 1 & $\mathbf{3}$ & 2 & - \\
\hline 4 & 2 & $\mathbf{3}$ & 1 & 1 & 1 & - & 2 & - & 2 & - & - \\
\hline 5 & 2 & $\mathbf{4}$ & 2 & 1 & - & 1 & - & 1 & - & 2 & - \\
\hline 6 & 2 & - & 1 & 1 & $\mathbf{3}$ & 2 & 1 & - & 2 & - & - \\
\hline 7 & 1 & - & 1 & - & 3 & 1 & 2 & 2 & - & $\mathbf{4}$ & \\
\hline 8 & 1 & 1 & 1 & $\mathbf{3}$ & - & - & 1 & 2 & 1 & 2 & 1 \\
\hline 9 & - & - & 2 & $\mathbf{4}$ & - & 3 & - & 2 & 2 & 1 & - \\
\hline 10 & 3 & 2 & 1 & 1 & $\mathbf{3}$ & 1 & $\mathbf{3}$ & - & - & - & - \\
\hline
\end{tabular}

Pogrubioną czcionką wyróżniono pozycje dominujące.

Jako najczęściej wykorzystywane źródła dydaktyczne studenci z tej grupy wymieniali:

- wykonywanie zdjęć materiałów dydaktycznych (3 osoby na pierwszym miejscu);

- kserowanie tekstów od kolegów (3 osoby na drugim miejscu);

- kserowanie tekstów przekazanych przez wykładowców (4 osoby na drugim miejscu);

- kserowanie książek w punkcie kserograficznym (4 osoby na czwartym miejscu);

- strony „chomikuj.pl” (3 osoby na czwartym miejscu).

Najrzadziej respondenci z tej grupy korzystali z:

- wypożyczania książek i wizyt w czytelni (9. i 10. miejsce);

- różnych form zakupów książek (5, 8. i 10. miejsce).

Najpopularniejszą formą pozyskiwania materiałów dydaktycznych przez studentów drugiego roku niestacjonarnych studiów licencjackich, podobnie jak w wypadku studentów ze studiów stacjonarnych, jest kserowanie tekstów zarówno przekazanych przez wykładowców, jak i udostępnianych przez kolegów bądź nabytych w punkcie kserograficznym. Niewielkie natomiast jest zainteresowanie korzystaniem z biblioteki i czytelni.

Kolejną analizowaną grupą byli studenci drugiego roku stacjonarnych studiów magisterskich. Wyniki ankietowania są zaprezentowane w tab. 4. Jak z niej wynika, najwięcej osób z tej grupy na pierwszym miejscu zamieściło korzystanie ze źródeł dydaktycznych w czytelni, a na drugim - wypożyczanie książek z biblioteki. Na trzecim i czwartym miejscu znalazły się odpowiednio: pozyskiwanie materiałów przez fotografowanie i kserowanie w punkcie świadczącym takie usługi. $\mathrm{Na}$ dalszych miejscach respondenci zamieścili kserowanie materiałów udostępnianych przez wykładowców i kolegów, natomiast na ostatnich miejscach znalazły się wszystkie formy zakupu książek, przy czym po cztery osoby wskazały, że nigdy nie korzystały z zakupów książek od wydawców ani ze stron „chomikuj.pl”. 
Tabela 4. Formy pozyskiwania źródeł przez studentów stacjonarnych studiów magisterskich (21 ankiet)

\begin{tabular}{|c|c|c|c|c|c|c|c|c|c|c|c|}
\hline Miejsce & I & II & III & IV & V & VI & VII & VIII & IX & X & 0 \\
\hline 1 & - & - & 1 & - & 2 & 1 & 3 & $\mathbf{7}$ & 4 & 2 & 1 \\
\hline 2 & 4 & $\mathbf{7}$ & 2 & - & 3 & 1 & 1 & 1 & 1 & 1 & - \\
\hline 3 & $\mathbf{8}$ & 2 & - & 4 & - & 4 & - & - & 3 & - & - \\
\hline 4 & - & 3 & 2 & 1 & 3 & $\mathbf{7}$ & 3 & 1 & - & 1 & - \\
\hline 5 & 2 & 2 & 2 & $\mathbf{5}$ & 4 & 1 & - & 2 & 1 & 2 & - \\
\hline 6 & - & - & 1 & 1 & - & - & 3 & - & 4 & $\mathbf{8}$ & 4 \\
\hline 7 & - & 1 & - & - & 1 & 1 & 1 & $\mathbf{6}$ & 5 & 2 & 4 \\
\hline 8 & 1 & 3 & - & 1 & 1 & 3 & $\mathbf{5}$ & 2 & - & 4 & 1 \\
\hline 9 & - & 1 & 4 & $\mathbf{7}$ & 3 & 2 & 3 & - & - & - & 1 \\
\hline 10 & 5 & 2 & $\mathbf{6}$ & 3 & 2 & 1 & 1 & 1 & - & - & - \\
\hline
\end{tabular}

Pogrubioną czcionką wyróżniono pozycje dominujące.

Ostatnią badaną grupą byli studenci z niestacjonarnych studiów magisterskich. Wyniki wypełnionych przez nich 10 ankiet są ujęte w tab. 5. Z ich ankiet nie wynika jednoznaczne preferowanie określonych form pozyskiwania materiałów dydaktycznych.

Tabela 5. Formy pozyskiwania źródeł przez studentów niestacjonarnych studiów magisterskich (10 ankiet)

\begin{tabular}{|c|c|c|c|c|c|c|c|c|c|c|c|}
\hline Miejsce & I & II & III & IV & V & VI & VII & VIII & IX & X & 0 \\
\hline 1 & $\mathbf{3}$ & 1 & - & 1 & 1 & 1 & - & - & 1 & - & 2 \\
\hline 2 & 1 & $\mathbf{2}$ & - & 1 & 1 & 1 & - & $\mathbf{2}$ & 1 & - & 1 \\
\hline 3 & - & - & 1 & 1 & 1 & $\mathbf{2}$ & 1 & 1 & 1 & - & - \\
\hline 4 & 1 & - & - & $\mathbf{3}$ & 1 & - & 4 & - & 1 & - & - \\
\hline 5 & 2 & 1 & $\mathbf{3}$ & 1 & 2 & - & - & 1 & - & - & - \\
\hline 6 & 1 & $\mathbf{3}$ & - & 1 & - & 1 & - & 1 & 1 & - & 2 \\
\hline 7 & 1 & - & 1 & 1 & - & - & 1 & - & - & 2 & $\mathbf{3}$ \\
\hline 8 & - & $\mathbf{2}$ & - & 1 & - & - & $\mathbf{2}$ & - & 1 & $\mathbf{2}$ & $\mathbf{2}$ \\
\hline 9 & - & - & $\mathbf{3}$ & - & $\mathbf{3}$ & 1 & - & 1 & 1 & 1 & \\
\hline 10 & 1 & 1 & 2 & - & - & $\mathbf{3}$ & - & 1 & - & 1 & 1 \\
\hline
\end{tabular}

Pogrubioną czcionką wyróżniono pozycje dominujące.

Najwięcej studentów z tej grupy, spośród form wskazywanych na pierwszym i drugim miejscu, wymieniło odpowiednio: tradycyjne zakupy książek i korzystanie z zakupów internetowych. Na kolejnych miejscach znalazły się formy takie, jak:

- kserowanie tekstów przekazanych przez wykładowców,

- kserowanie tekstów udostępnionych przez kolegów,

- kserowanie książek w punkcie kserograficznym,

- wykonywanie zdjęć materiałów dydaktycznych.

Jak w innych grupach ankietowanych, także w tej grupie najwięcej osób - wskazując formę pozyskiwania źródeł, z której nigdy nie korzystały - wymieniło zakupy książek od wydawców. Jest to jedyne podobieństwo, ponieważ w innych wypadkach wyniki tej grupy różnią się od wyżej omówionych grup następującymi cechami:

- nie występują w tej grupie wyraźne preferencje co do określonych form, w związku z czym wybory sposobów pozyskiwania źródeł rozkładają się równomiernie; 
- nie pojawia się „zagęszczenie” wyborów dotyczących ostatnich miejsc (6-10);

- studenci z tej grupy, jako jedyni, w pierwszej kolejności wskazali zakupy książek jako źródło pozyskiwania materiałów dydaktycznych.

\section{PODSUMOWANIE}

Z przedstawionej analizy dokonywanych przez studentów wyborów w zakresie form pozyskiwania materiałów dydaktycznych wynika, że studenci studiów I stopnia rzadko kupują nowe książki lub korzystają z wypożyczeń bibliotecznych i czytelni. Przygotowując się do zaliczeń i egzaminów, wykorzystują głównie kserokopie materiałów zawierających wiedzę przekazywaną na zajęciach, nie dążąc do jej wzbogacenia. Zjawisko to jest najbardziej nasilone w wypadku studentów pierwszego roku studiów licencjackich.

Wypożyczanie książek i korzystanie z czytelni były znacznie częściej wskazywane przez osoby piszące prace magisterskie. Można sądzić, że wynika to, między innymi, z konieczności podawania w przypisach dokładnych danych o wykorzystanych źródłach. Strony internetowe nie są natomiast traktowane jako naukowe źródło informacji, nawet jeżeli mają podaną datę dostępu. Osoby ze studiów II stopnia mają też większe doświadczenie w studiowaniu; ich wybory są bardziej świadome i ambitne.

W celu sporządzenia listy rankingowej form pozyskiwania materiałów dydaktycznych przez studentów z analizowanych grup została opracowana zbiorcza punktacja sposobów pozyskiwania przez studentów źródeł dydaktycznych poprzez zsumowanie wyborów tych źródeł (por. tab. 6). Im mniejsza jest suma punktów, tym lepsze miejsca zajmowała dana forma, ponieważ była wybierana w pierwszej, drugiej lub trzeciej kolejności. Im natomiast większa jest suma punktów przypisanych danej formie, tym dalsze miejsca zajmowała ona w wyborach studentów.

Tabela 6. Punktacja form pozyskiwania źródeł dydaktycznych przez ankietowanych studentów

\begin{tabular}{|c|c|c|c|c|c|c|c|c|}
\hline \multirow{3}{*}{ Nr pytania } & \multicolumn{4}{|c|}{ Studia niestacjonarne } & \multicolumn{4}{|c|}{ Studia stacjonarne } \\
\hline & \multicolumn{2}{|c|}{ licencjackie } & \multicolumn{2}{|c|}{ magisterskie } & \multicolumn{2}{|c|}{ licencjackie } & \multicolumn{2}{|c|}{ magisterskie } \\
\hline & $\begin{array}{c}\text { suma } \\
\text { punktów }\end{array}$ & miejsce & $\begin{array}{c}\text { suma } \\
\text { punktów }\end{array}$ & miejsce & $\begin{array}{c}\text { suma } \\
\text { punktów }\end{array}$ & miejsce & $\begin{array}{c}\text { suma } \\
\text { punktów }\end{array}$ & miejsce \\
\hline 1 & 72 & 3 & 29 & 1 & 213 & 6 & 51 & 7 \\
\hline 2 & 99 & 9 & 45 & 5 & 209 & 5 & 19 & 1 \\
\hline 3 & 102 & 10 & 53 & 8 & 257 & 10 & 20 & 2 \\
\hline 4 & 56 & 1 & 55 & 9 & 174 & 3 & 31 & 5 \\
\hline 5 & 56 & 2 & 35 & 3 & 158 & 2 & 23 & 4 \\
\hline 6 & 75 & 5 & 34 & 2 & 218 & 7 & 58 & 9 \\
\hline 7 & 95 & 8 & 35 & 4 & 247 & 9 & 63 & 10 \\
\hline 8 & 73 & 4 & 51 & 7 & 224 & 8 & 53 & 8 \\
\hline 9 & 84 & 7 & 57 & 10 & 207 & 4 & 35 & 6 \\
\hline 10 & 78 & 6 & 45 & 6 & 154 & 1 & 21 & 3 \\
\hline
\end{tabular}

Pogrubioną czcionką wyróżniono pozycje dominujące.

Z podsumowania wynika, że na licencjackich studiach stacjonarnych na pierwszym miejscu znalazło się wykonywanie zdjęć materiałów dydaktycznych, natomiast na studiach niestacjonarnych - kserowanie tekstów udostępnionych przez kolegów. W wypadku 
stacjonarnych studiów magisterskich na pierwszym miejscu znalazło się wypożyczanie książek, zaś na studiach niestacjonarnych - zakupy książek.

Najwięcej punktów, czyli ostatnie miejsce na stacjonarnych i niestacjonarnych studiach licencjackich, odnotowano w przypadku korzystania z czytelni (wizyty w bibliotece), co należy uznać za sprzeczne z ideą studiowania. Wydaje się, że ten wynik powinien zmobilizować prowadzących zajęcia oraz pracowników bibliotek i czytelni do zachęcania i uświadamiania studentom tego, jak niezbędna jest ta forma pozyskiwania materiałów do uczenia się w wypadku osób, które studiują i które powinny wyrobić sobie nawyk stałego pogłębiania wiedzy jako warunek sukcesu zawodowego. Na stacjonarnych studiach magisterskich na ostatnim miejscu plasują się zakupy książek od wydawców, natomiast na studiach niestacjonarnych - kserowanie książek w punkcie kserograficznym. Biorąc pod uwagę pozycje zajmujące pierwsze miejsca w wypadku studiów magisterskich, należy uznać, że na tych studiach sytuacja jest o wiele lepsza niż na studiach licencjackich.

\section{PIŚMIENNICTWO}

Jankowska D., Leśnikowska-Matusiak I. 2011. Współczesne metody uczenia się ludzi dorosłych i ich wykorzystanie w edukacji bezpieczeństwa ruchu drogowego. Logistyka 3, 971.

Janowicz M. 2017. Wybrane aspekty uczenia się. Wyniki badań. Folia Pomer. Univ.Technol. Stetin., Oeconomica 335(87)2, 82-83.

Michalski R.S. 1993. Inferential theory of learning as a conceptual basis for multistrategy learning, in: Multistrategy learning. Red. R.S. Michalski. Norwell, Springer, 5-6.

Streszczenie. Korzystanie z materiałów dydaktycznych jest jednym z podstawowych czynników warunkujących samodzielną pracę studentów w zdobywaniu i poszerzaniu wiedzy. Sposoby ich pozyskiwania mogą być różne, przy czym ich wybór wpływa na jakość i efekty procesu uczenia się. Celem artykułu było zbadanie i wskazanie najpopularniejszych form pozyskiwania materiałów dydaktycznych przez studentów. Do jego realizacji zastosowano metodę badań ankietowych, którymi objęto 101 studentów studiów stacjonarnych i niestacjonarnych I i II stopnia z kierunku finanse i rachunkowość z Wydziału Nauk Ekonomicznych i Zarządzania Uniwersytetu Szczecińskiego. Wyniki wyboru przez ankietowanych określonych form pozyskiwania materiałów dydaktycznych wskazują, iż studenci studiów I stopnia fotografują lub kserują materiały udostępniane przez wykładowców lub kolegów, co oznacza, iż ograniczają się do wiedzy przekazywanej na zajęciach. Do poszerzania swojej wiedzy dążą natomiast studenci studiów stacjonarnych i niestacjonarnych II stopnia, o czym świadczą dominacja wypożyczeń bibliotecznych, korzystanie z czytelni i zakupy książek. 
